\title{
Consumer Acceptance of Quality Protein Maize (QPM) in East
}

\section{Africa}

Hugo De Groote ${ }^{1 *}$, Nilupa S. Gunaratna ${ }^{2}$, James O. Okuro ${ }^{3}$, Asrat Wondimu ${ }^{4}$, Christine Kiria Chege ${ }^{5}$, and Keith Tomlins ${ }^{6}$

${ }^{1}$ International Maize and Wheat Improvement Centre (CIMMYT), PO Box 2041-00621 Nairobi; h.degroote@cgiar.org

${ }^{2}$ Harvard School of Public Health, 677 Huntington Avenue, Boston, MA 02115 USA; ngunarat@hsph.harvard.edu

${ }^{3}$ Kenya Agricultural Research Institute (KARI), P.O. Box 27-60100, Embu, Kenya; j_okuro@yahoo.co.uk

${ }^{4}$ Food Science and Nutrition Research Directorate, Ethiopian Public Health Institute (previously Ethiopian Health and Nutrition Institute, EHNRI), Gulelle Arbegnoch Street, Addis Ababa, Ethiopia; asrat1976@yahoo.com

${ }^{5}$ University of Pretoria; Department of Agricultural Economics, Extension and Rural Development, Private bag X20 Hatfield, Pretoria 0026, South Africa (currently at Georg-August-University of Goettingen, Germany); xtinahg@yahoo.com

${ }^{6}$ Natural Resources Institute, University of Greenwich, Greenwich, Medway Campus, Central Avenue, Chatham Maritime ME4 4TB, United Kingdom; K.I.Tomlins@ greenwich.ac.uk

* Corresponding author. Tel.: +254 20 7204600, fax +254 20 7204601. E-mail address: h.degroote@cgiar.org

\begin{abstract}
Background: Undernutrition in sub-Saharan Africa remains problematic, and quality protein maize (QPM) can benefit populations whose diets are heavily based on maize and who are consequently at risk for inadequate intakes of quality protein. However, the changes in QPM's chemical composition may affect its sensory characteristics and, hence, acceptance. Acceptance tests were, therefore, conducted to evaluate QPM varieties in three East African countries using central location tests with one or two varieties in each country, using the most popular preparations: ugali (Tanzania), githeri (Kenya), and injera (Ethiopia). In total, 281
\end{abstract}


urban and rural consumers of both sexes and varying levels of education evaluated the products on standard sensory criteria: appearance, aroma, texture, taste, and overall, using a Likert scale.

Results: The results show African consumers can differentiate QPM products from their conventional counterparts, indicating that the QPM trait results in distinguishable sensory changes. Analysis by ordinal mixed regression models showed that consumers found QPM acceptable and even preferable to conventional maize.

Conclusion: The sensory characteristics of QPM are, therefore, no impediment to its adoption; on the contrary, when coupled with good agronomic performance, they may help its utilization, leading to a positive impact in nutritionally vulnerable populations.

Keywords: quality protein maize, East Africa, consumer acceptance, affective test, ordinal regression, mixed model

\section{INTRODUCTION}

Despite global efforts towards the first Millennium Development Goal to eradicate extreme poverty and hunger, large disparities in progress exist regionally ${ }^{1}$. Progress has slowed towards nutritional goals, in large part due to poor prospects in all regions of subSaharan Africa ${ }^{2}$. Moreover, food production can barely keep up with the still rapidly increasing population, especially in Africa, where per capita food production in the last decennium was lower than in the $1960 \mathrm{~s}^{3}$.

To improve this situation, plant breeders are developing new crop varieties with increased nutritional value, such as quality protein maize (biofortified with essential amino acids) or orange fleshed sweet potato, yellow cassava and orange maize (biofortified with

provitamin A carotenoids) ${ }^{4}$. Biofortification of staple crops is a cost-effective way to improve the diets of rural populations, which are often of the poorest quality, and to improve their nutritional status 5,6 .

For biofortified crops to be adopted and, hence, improve the nutritional status and health of target populations, they must be appreciated in their common food preparations. Biofortification can alter the organoleptic qualities of crops, however, so their consumer acceptability needs to be tested. Because sensory evaluation techniques have largely been developed for urban consumers in developed countries, special care is needed to ensure that 
methods are appropriate and, where necessary, adapted to the special needs and characteristics of the poor consumer, who may be illiterate and have limited experience in this type of exercise. The main target of biofortified crops is rural households that mostly consume their own production, and their common food preparations using these staples should receive particular attention.

In East and Southern Africa, the major staple food is maize, which has a poor balance of essential amino acids ${ }^{7}$. People whose diets are based on maize and who have limited access to legumes and animal food sources are, therefore, at risk of inadequate intakes of quality protein and, in particular, lysine ${ }^{8}$. To counter maize's poor amino acid balance, quality protein maize (QPM) was developed with higher levels of lysine and tryptophan than conventional maize ${ }^{9}$. QPM is based on the discovery in the 1960 s of a specific gene, opaque2 (o2), that almost doubles the lysine and tryptophan content of the maize endosperm, improving dramatically its protein quality ${ }^{10}$. Unfortunately, the $o 2$ gene was also associated with soft opaque kernels and poor agronomic performance. Over a period of almost 30 years of targeted conventional plant breeding, these problems were overcome using natural genetic modifiers. A group of new maize varieties, collectively called QPM, was developed with improved protein quality as well as agronomic and storage qualities similar to conventional maize $^{9,11}$.

Randomized, controlled trials in several developing countries have demonstrated the positive effect of QPM consumption on the nutritional status of children, in particular in Ethiopia ${ }^{12}$, India ${ }^{13}$, and Nicaragua ${ }^{14}$. A meta-analysis of nine of these trials in five countries showed that consumption of QPM instead of conventional maize leads to a $12 \%$ increase in the rate of growth in weight and a $9 \%$ increase in the rate of growth in height in infants and young children with mild to moderate under-nutrition from populations in which maize is the major staple food ${ }^{15}$.

However, to have nutritional impact, consumers must accept QPM varieties in the preparation of common foods in local diets. The $o 2$ gene changes the protein composition and stacking of starch in the endosperm ${ }^{11,16}$. The appearance of the kernel is also altered to a soft, chalky phenotype that is unattractive to maize growers in developing countries ${ }^{9}$. In Colombia, however, $o 2$ maize showed good acceptability in most preparations tested ${ }^{17}$, although with a three-point Likert scale and only 20 participants, differences were hard to distinguish.

In developing QPM, plant breeders specifically selected for conventional kernel characteristics along with improved protein quality. Therefore, these conventional kernel 
characteristics, which are expected by farmers, are a required feature of modern QPM varieties. However, having conventional kernel characteristics does not ensure that a variety will have similar or equally acceptable sensory characteristics as conventional maize, necessitating consumer acceptance testing. In Ghana, QPM varieties were preferred to the local conventional maize in some preparations and were equally accepted in others ${ }^{18}$. In Nigeria, finally, sensory evaluation of stiff porridge prepared from QPM and conventional maize varieties showed no significant difference in flavor, taste, color or overall acceptability 19

Currently, QPM varieties are being disseminated and promoted in East Africa ${ }^{20}$, but their acceptance among consumers has not yet been studied. The limited number of past consumer acceptance studies on QPM had methodological issues in both their design and analysis. In particular, researchers as well as participants were often aware of the identity of varieties being evaluated, allowing personal biases to play a role in evaluation. Studies using a single QPM variety or a single conventional maize variety were not able to attribute differences in consumer acceptance specifically to the quality protein trait, as those differences could be due to other characteristics specific to the variety being tested. Other factors that affect participants' responses, such as participant demographics, the order in which food samples were presented, and other characteristics of the evaluation, were not considered or controlled. Finally, evaluations were typically done using ordinal scales with multiple evaluations by each participant, but analyses did not account for the nature and correlated structure of these data. In this study, therefore, we assessed consumer acceptance with affective tests using locally available QPM varieties in three common food preparations in the three major East African maize-producing countries, while making several methodological improvements.

\section{METHODOLOGY}

\section{Concepts and overview}

Consumers derive satisfaction, not from the goods themselves, but from the attributes these provide ${ }^{21}$. Therefore, sensory properties are an important part of the study of consumer acceptance of new food products, and typically involve several criteria, such as smell or taste, which emanate from a combination of attributes. The importance of the attributes or criteria not only depends on the specific product, but also on its preparation, the cultural 
environment, and consumers' socioeconomic characteristics. To evaluate a product, consumers are asked to use a particular metric or scale ${ }^{22}$, often a Likert scale ${ }^{23}$. In sensory evaluation, a trained panel tries to objectively judge the new products on the different criteria, while in affective tests, regular consumers are asked in how far they like the products, based on a limited range of criteria. Affective tests are preferably conducted with randomly selected participants, while the evaluation should be double-blind, and the order of presentation random.

Because this was the first time to evaluate QPM in East Africa, and the budget was limited, the central location method ${ }^{22}$ was preferred. This method allows for many people to participate in a relatively short time in a well-controlled environment. The three countries with the highest levels of maize production and consumption in the region were selected: Kenya, Ethiopia and Tanzania. Within each country, the place or region was chosen based on the availability of grain and the dissemination activities of the Quality Protein Maize Development (QPMD) project. In each country, QPM and conventional maize were evaluated with the most important maize preparation in the country or region, on the standard sensory criteria, organized by teams from the respective collaborating organizations of the QPMD project.

\section{Study design}

In all countries, the study took place in a central, urban location, complemented with two central rural locations in Kenya. All participants were adults, both men and women, with varying degrees of education. Before consumer acceptance, information was collected on individual characteristics such as gender, age and education. The methods were first developed and tested with urban consumers in a small urban centre in Kenya (Embu), for convenience and cost reasons, and subsequently adapted and used with nearby rural consumers. In the next country, Ethiopia, the study only took place in the capital because for budgetary reasons, but care was taken to include consumers from a wide range of backgrounds, including scientists, students and illiterate workers. In Tanzania, finally, the research station were the study took place is situated on the outskirts of the provincial capital, Arusha, and the food consumption habits of its staff were likely similar to the rural households around them. These studies were the start of wider range of studies to develop the methods for the ultimate target audience, rural consumers. 
The first evaluations were conducted in Kenya, in November and December 2007, by the Kenya Agricultural Research Institute (KARI) at one urban center and two rural communities in Embu District. The urban evaluation took place at the Agricultural Training Centre (ATC) in Embu. Notices were posted at KARI and ATC to invite volunteers, and 25 men and 25 women participated. The rural evaluations were conducted with two farmer groups: in Mukuria sub-location (Kyeni Division), with a group of single HIV-positive mothers of which 57 participated, and in Itabua sub-location (Central Division), with a mixed group of which 14 men and 10 women participated.

In Ethiopia, the sensory evaluation was conducted in December 2009 by the Ethiopian Health and Nutrition Research Institute (EHNRI), in their food science laboratory in Addis Ababa. Volunteers were recruited from among educated staff members, of which 60 participated (34 women), students affiliated with the institute (with 30 participants, of which 15 were female) and staff with limited or no schooling (30 participants, of which 19 were women). Because of the complex design and large number of products (nine), each volunteer participated in two sessions on separate days, with five products evaluated per session.

The last country was Tanzania, where the evaluations were organized in January 2010, by the Selian Agricultural Research Institute (SARI), at their station in Arusha, the regional capital. Volunteers from the SARI staff were invited, and 30 participated, of which 12 were women.

To facilitate the presentation and the understanding, however, from here on we will present the methods and the results from the simpler to the more complex design, starting with Tanzania, followed by Kenya, and ending with Ethiopia.

\section{The products}

The products evaluated were different preparations, made from QPM or conventional maize varieties, or mixed with teff in Ethiopia. While ideally, QPM varieties converted from conventional varieties should be paired with their conventional counterpart to isolate the QPM trait in the evaluation, no such near-isogenic pairs were available. In Tanzania, only one QPM variety, Lisle K1, was available, and it was compared to conventional maize purchased as grain from the market, but the variety could not be identified. In Kenya, two QPM varieties were available, KH631Q and WSQ104, and they were evaluated along with two popular conventional maize varieties, Embu Composite (EMCO) and KH513. In 
Ethiopia, four varieties were evaluated, paired by their targeted agro-ecological zone: the medium maturing BH540 and its QPM counterpart BHQP542; and the dryland variety Melkassa 2 and its QPM counterpart Melkassa 6Q.

In each country, participants compared the QPM and conventional maize (CM) varieties using the most commonly consumed preparation for the region (Table 1). In Tanzania, this preparation was ugali, a stiff, unfermented porridge, prepared by gradually adding maize flour to boiling water and stirring continuously until cooked. Ugali is the most common staple food in Tanzania ${ }^{24}$ and is also popular in Kenya ${ }^{25}$. The product was prepared in the kitchen of the institute by one single cook. Both varieties were purchased from the local market, milled locally, packed and labeled with a triangle for QPM and a circle for conventional maize, so neither the cook, the enumerators nor the participants knew which one was QPM.

Table 1. Study design with number of sites and participants, products and varieties, and evaluation criteria, by country

\begin{tabular}{|c|c|c|c|c|}
\hline Factor & Category & Tanzania & Kenya & Ethiopia \\
\hline \multirow[t]{2}{*}{ Sites } & Urban & $\begin{array}{l}\text { Arusha } \\
\text { (SARI) }\end{array}$ & Embu (ATC) & $\begin{array}{c}\text { Addis Ababa } \\
\text { (EHNRI) }\end{array}$ \\
\hline & Rural & \multicolumn{3}{|c|}{ Mukuria and Itabua } \\
\hline Number of participants & & 30 & 131 & 120 \\
\hline Maize preparation tested & & Ugali & Githeri & Injera \\
\hline \multirow[t]{2}{*}{ Ingredients } & $\begin{array}{l}\text { Product } 1 \\
\text { Product } 2\end{array}$ & Maize & Maize and beans & $\begin{array}{l}\text { Maize and teff } \\
(50 \%-50 \%) \\
\text { Maize and teff } \\
(80 \%-20 \%)\end{array}$ \\
\hline & Product 3 & & & Teff \\
\hline \multirow[t]{5}{*}{ Varieties } & QPM Variety 1 & Lishe K1 & KH631Q & BHQP542 \\
\hline & QPM Variety 2 & & WSQ104 & Melkassa 6Q \\
\hline & CM Variety 1 & Local grain & EMCO & BH540 \\
\hline & CM Variety 2 & & H513 & Melkassa 2 \\
\hline & Appearance & $\checkmark$ & $\checkmark$ & $\checkmark$ \\
\hline \multirow[t]{7}{*}{ Criteria included in evaluation } & Aroma & $\checkmark$ & & $\checkmark$ \\
\hline & Pliability & & & $\checkmark$ \\
\hline & Texture & & $\checkmark$ & \\
\hline & Texture in hand & $\checkmark$ & & $\checkmark$ \\
\hline & Texture in mouth & $\checkmark$ & & $\checkmark$ \\
\hline & Taste & $\checkmark$ & $\checkmark$ & $\checkmark$ \\
\hline & Overall acceptance & $\checkmark$ & $\checkmark$ & $\checkmark$ \\
\hline
\end{tabular}


In Kenya, the major maize preparation of the region was identified by farmers during Participatory Rural Appraisals ${ }^{26}$ as githeri, a mixture of boiled maize kernels and beans in a ratio of 2:1. Githeri is popular in other parts of the country, including the capital where it ranks second after ugali $^{25}$. The four varieties were identified by randomly generated threedigit codes, only known to the lead researcher.

In Ethiopia, the most common staple food is injera, a leavened bread made from fermented dough ${ }^{27}$. Traditionally, it is made from teff, an indigenous cereal, but it is often mixed with other cereals, especially with the much cheaper maize. A study conducted at the Awassa College of Agriculture found that injera made from a mix of teff, wheat, sorghum and maize flour, each at $25 \%$, was acceptable in sensory evaluation. The mixture was $36.6 \%$ cheaper than pure teff, and the nutritional value was slightly better ${ }^{28}$. For this study, nine injera products were evaluated: one from pure teff, and eight from maize/teff mixtures, with either $50 \%$ or $80 \%$ maize from one of the four maize varieties. Each variety was coded with a randomly generated three-digit code.

\section{Scoring for different criteria}

All products were evaluated on the basic sensory criteria using a standard Likert scale ${ }^{23}$. In Tanzania, participants were staff members of SARI, all with secondary education or more, so the more precise 9-point scale was used. The scale was centered on a value of 5 (average), with the lowest value 1 (= extremely bad), the highest 9 (= extremely good), and other qualifications were "moderately" and "very". Elsewhere, farmers and illiterate workers participated, so the simpler five-point scale was used ("very bad", "bad", "fair", "good", and "very good"). This basic scale can be used in most languages and on most relevant criteria, even orally, but is less precise and clearly an ordinal variable, requiring specific statistical methods ${ }^{29}$. The terms "good" and "bad" are common verbal qualifiers for rating scores and a comparative study found them appropriate to evaluate quality levels ${ }^{30}$. We found them the easiest to translate accurately in the languages used during evaluations and discussions (English and Kiswahili in Tanzania, Kiembu in Kenya, and Amharic in Ethiopia). They allow the scale to remain balanced and hence suitable for statistically analysis and can be interpreted within the context of the experiment.

The four general criteria in sensory evaluation are appearance, aroma, texture and taste. Because many African dishes are consumed using the hands, the texture in the hand was evaluated separately from the texture in the mouth in Tanzania and Ethiopia. In 
Tanzania, discussions with focus groups and key informants informed the choice of the criteria. In Kenya, the evaluation criteria for githeri were elicited during group discussions in Kiembu, the local language of the district, resulting in taste, texture, and appearance. In Ethiopia, sensory evaluation of injera is frequently done at EHNRI, and involves the standard criteria as in Tanzania. But because injera is also used to pick up sauces and other food items, its pliability is also considered important. For cross-country comparison, an overall evaluation was added to all products.

The participants evaluated each food preparation in randomly assigned orders and did not return to re-evaluate an earlier preparation. Drinking water was provided between evaluations of each preparation to minimize the effect of previous scores on subsequent scores, but no sauce or side-dishes were provided. In Tanzania and Kenya, the products were offered in randomized order. In Ethiopia, the nine products were split into two rounds: one round contained the control injera from pure teff and injera from 50\% maize mixtures using each of the four varieties, while the other round contained the control injera from pure teff and injera from $80 \%$ maize mixtures using the four varieties. The rounds were randomly assigned, and within each round, the five treatments were presented in a randomized order. All studies were double-blind, i.e., neither the researchers nor the participants knew which maize variety was used to make any of the food preparations.

\section{Sample size}

The number of participants in Ethiopia and Kenya was determined using the sample size formula for paired data derived by Connett et al. ${ }^{31}$, which provides an upper bound on the required number of discordant responses ${ }^{32,33}$. Assuming $80 \%$ power, a 0.05 significance level, pairs of responses distributed uniformly over a five-point scale (i.e., a proportion of discordant pairs of 0.8), and an odds ratio for discordant pairs of 1.8, then at least 118 participants were required in each country. The sample size in Tanzania was limited by available resources and was sufficient to detect an odds ratio of 3.2 using a nine-point scale.

\section{Analysis}

The 9-point scale used in Tanzania can be argued to approximate an interval variable, so means were first compared with a paired t-test to analyze if the difference was significantly different from zero. In Kenya and Ethiopia, the 5-point scale was used, which is clearly ordinal ${ }^{29}$, and for which the preferred analysis is ordinal regression ${ }^{34,35}$. Because 
each respondent was asked to evaluate several products, an individual random effect was added to account for differences in scoring among respondents and correlation of scores from the same respondent ${ }^{36}$.

Ordered-response models typically assume that the scores represent ordered segments of a utility distribution ${ }^{37}$. The values of the latent variable $U$ represent quantities and dcan be analyzed using standard quantitative methods such as the linear model ${ }^{38}$ :

$$
U_{i}=\boldsymbol{\beta}^{\prime} \boldsymbol{x}_{i}+\varepsilon_{i},
$$

where $U_{i}$ represents the utility of individual $i, \boldsymbol{x}_{i}$ is a vector of variables influencing the $i^{\text {th }}$ individual's utility and choice, $\beta$ is a vector of parameters to be estimated and $\varepsilon_{\mathrm{i}}$ is the error term. The probability of the scores $y$ can now be derived from this model by assuming the error term $\varepsilon$ has a logistic distribution ${ }^{39}$, and the log-likelihood function can be constructed and maximized to estimate the parameters. Let $v_{\mathrm{k}}=P(y \leq k)$, or the probability that a score $y$ falls at or below a certain level $k$, and the logit, or the logarithm of the odds of $v_{\mathrm{k}}$, can then be modeled as a linear function of the independent variables, formally:

$$
\operatorname{Logit}\left(v_{k}\right)=\operatorname{Ln} \frac{P(y \leq k)}{1-P(y \leq k)}=\alpha_{k}+\beta^{\prime} \mathbf{x}
$$

It follows that the ratio of the odds of the event $y \leq k$ at $\boldsymbol{x}=\mathrm{x}_{1}$ and $\boldsymbol{x}=\mathrm{x}_{2}$ is independent of the level $k$, and that the log of the cumulative odds for all the categories $\mathrm{k}$ are linear (or proportional) to the independent variables, regardless of $\mathrm{k}$, hence the name 'proportional odds' model ${ }^{34}$, also called the ordered logit model ${ }^{38,39}$. The coefficient $\boldsymbol{\beta}$ represents a change in the log odds (the logarithm of the odds) for a unit change in the explanatory variable $\boldsymbol{x}$. Hence, if $x$ is binary, as when comparing a new product to an old one, the coefficient $\boldsymbol{\beta}$ represents the change in the log odds due to the new product. Its exponent, $e^{\beta}$, represents the odds that the new product is rated higher over the odds for the old product, 
also called the odds ratio ${ }^{40}$. The proportional odds assumption can be evaluated using a score test (Peterson and Harrell 1990).

To analyze the effect of the products on the scores from the sensory evaluation, let $\boldsymbol{x}_{j}$ be a vector of attributes for product $j$, and $\boldsymbol{\beta}$ a vector of parameters. Adding a random individual effect $u_{i}$, the model becomes:

$$
\operatorname{Logit}\left(v_{i j k}\right)=\alpha_{k}+\boldsymbol{\beta} \boldsymbol{x}_{\boldsymbol{j}}+u_{i}
$$

The order of presentation and other aspects of the study design can be included in the set of attributes, $\boldsymbol{x}_{\boldsymbol{j}}$, and consumer acceptance can now conveniently be analyzed by the coefficients of this short model.

Evaluation of new products can also differ by the characteristics of the consumers, in particular gender, education, and age. To analyze the combined effects of the product attributes $j$ and consumer characteristics $i$ on the cumulative odds of score $y_{i j,}$, a mixed effects model was used with a product attributes vector $\boldsymbol{x}_{j}$, a consumer characteristics vector $\boldsymbol{z}_{i}$, a cross effects matrix $A$, and an individual disturbance $u_{i}{ }^{41}$ :

$$
\operatorname{Logit}\left(v_{i j k}\right)=\alpha_{k}+\boldsymbol{\beta} \boldsymbol{x}_{\boldsymbol{j}}+\boldsymbol{\gamma}^{\prime} z_{i}+\boldsymbol{x}_{j}^{\prime} A z_{i}+u_{i}+v_{i j}
$$

This long model allows analysis of the effects of both product and consumer characteristics, as well as their cross effects, while taking into account the possible correlation between scores for different products by the same consumer.

\section{RESULTS}

\section{Characteristics of participants}

About two thirds of all participants were female, but it was slightly more in Kenya, where one of the participating groups was a women-only group (Table 2). All respondents were adults, with an average age of 39 years. The respondents in urban Kenya were relatively younger (33), as were the students in Ethiopia (20), while the rural respondents in Kenya were older (43 among the women's group, 54 among the mixed group).

Most respondents were educated, with an average level of 10 years. Education was highest in Tanzania (15 years), where all respondents came from the staff of the research 
Table 2. Characteristics of the participants

\begin{tabular}{|c|c|c|c|c|c|c|c|c|c|}
\hline \multirow[t]{2}{*}{ Characteristics } & \multirow{2}{*}{$\begin{array}{c}\text { Tanzania } \\
\text { All } \\
(\mathrm{n}=30) \\
\end{array}$} & \multicolumn{4}{|c|}{ Kenya } & \multicolumn{4}{|c|}{ Ethiopia } \\
\hline & & $\begin{array}{l}\text { Embu } \\
(\mathrm{n}=50)\end{array}$ & $\begin{array}{c}\text { Mukuria } \\
(\mathrm{n}=57)\end{array}$ & $\begin{array}{l}\text { Itabua } \\
(\mathrm{n}=24)\end{array}$ & $\begin{array}{c}\text { All } \\
(\mathrm{n}=131)\end{array}$ & $\begin{array}{l}\text { Staff with } \\
\text { education } \\
(n=60)\end{array}$ & $\begin{array}{l}\text { Students } \\
(\mathrm{n}=30)\end{array}$ & $\begin{array}{c}\text { Staff } \\
\text { without } \\
\text { education } \\
(\mathrm{n}=30)\end{array}$ & $\begin{array}{c}\text { All } \\
(\mathrm{n}=120)\end{array}$ \\
\hline Female (\%) & 40 & 50 & 100 & 42 & 70 & 56 & 50 & 63 & 58 \\
\hline $\begin{array}{l}\text { Age }^{\mathrm{a}} \text { (years) } \\
\text { (st. dev.) }\end{array}$ & $\begin{array}{r}42.3 \\
(10.4)\end{array}$ & $\begin{array}{r}33.1 \\
(10.1)\end{array}$ & $\begin{array}{r}43.2 \\
(16.2)\end{array}$ & $\begin{array}{r}54.0 \\
(14.1)\end{array}$ & $\begin{array}{r}41.4 \\
(15.6)\end{array}$ & $\begin{array}{r}30.3 \\
(10.0)\end{array}$ & $\begin{array}{l}20.0 \\
(1.9)\end{array}$ & $\begin{array}{l}44.0 \\
(8.8)\end{array}$ & $\begin{array}{r}33.7 \\
(11.4)\end{array}$ \\
\hline $\begin{array}{l}\text { Education } \\
\text { (years) } \\
\text { (st. dev.) }\end{array}$ & $\begin{array}{l}15.1 \\
(4.9)\end{array}$ & $\begin{array}{l}11.8 \\
(3.4)\end{array}$ & $\begin{array}{r}7.9 \\
(7.3)\end{array}$ & $\begin{array}{r}8.4 \\
(3.7)\end{array}$ & $\begin{array}{r}9.5 \\
(5.7)\end{array}$ & $\begin{array}{l}14.5 \\
(2.0)\end{array}$ & $\begin{array}{l}14.2 \\
(1.3)\end{array}$ & $\begin{array}{r}0.0 \\
(0.0)\end{array}$ & $\begin{array}{l}10.9 \\
(6.5)\end{array}$ \\
\hline $\begin{array}{l}\text { Farming } \\
\text { experience } \\
\text { (years) } \\
\text { (st. dev.) }\end{array}$ & $\begin{array}{l}- \\
-\end{array}$ & , & $\begin{array}{r}21.6 \\
(17.0)\end{array}$ & $\begin{array}{r}22.6 \\
(12.3)\end{array}$ & $\begin{array}{r}21.9 \\
(15.6)\end{array}$ & $\begin{array}{l}- \\
-\end{array}$ & & $\begin{array}{l}- \\
-\end{array}$ & $\begin{array}{l}- \\
-\end{array}$ \\
\hline $\begin{array}{l}\text { Farm size (acres) } \\
\text { (st. dev.) }\end{array}$ & & $\begin{array}{l}- \\
-\end{array}$ & $\begin{array}{r}2.9 \\
(3.2)\end{array}$ & $\begin{array}{r}2.7 \\
(2.2)\end{array}$ & $\begin{array}{r}2.8 \\
(3.0)\end{array}$ & $\begin{array}{l}- \\
-\end{array}$ & & $\begin{array}{l}- \\
-\end{array}$ & $\begin{array}{l}- \\
-\end{array}$ \\
\hline
\end{tabular}

${ }^{a}$ values are means (with standard deviations in brackets) or percentages as indicated 
institute. Education of respondents was high in urban Kenya (12 years), and in Ethiopia among the educated staff (15) and the students (14). Education was lowest in rural Kenya (but still eight years on average), and among the uneducated staff in Ethiopia. The respondents in rural Kenya were all farmers, with an average farm size of 2.8 acres and an average farming experience of 22 years.

\section{Consumer acceptance of ugali in Tanzania}

In Tanzania, 30 staff members of the collaborating research institute, SARI, evaluated the acceptance of ugali, a stiff maize porridge, made from either QPM or conventional maize. Participants were asked to evaluate samples made from both maize types, on five different criteria and overall, on a 9-point Likert scale $(1=$ extremely bad, $2=$ very bad, $3=$ bad, $4=$ moderately bad, 5 = fair, $6=$ moderately good, $7=$ good, $8=$ very good, and $9=$ extremely good). From the nine options, however, very few participants used the four lowest ratings, and $99 \%$ of the responses were in the categories "fair" or better.

In a first analysis, assuming the scores approximate interval variables, the mean scores were compared (Table 3). The results show that QPM ugali is generally preferred over its CM counterpart: in the overall evaluation it received an average score of 1.1 units higher, and it also scored better for all criteria except for appearance. The scores for QPM were significantly larger for texture in mouth (1.3), for taste (1.4), and, to a lesser extent, for the related aroma (0.9).

Because the scores are ordinal variables, ordinal regression is indicated as it does not assume the data follow a continuous interval scale. The estimation of the short model (Equation 3) indicates that consumers did not distinguish between the appearance of QPM and CM ugali and found them similarly acceptable (Table 3). For all other criteria, however, QPM scored better, as indicated by the sign and the significance of the coefficients. The coefficients for QPM in the ordinal regression are log-odds ratios. For better interpretation, they can be transformed into odds-ratios by taking the exponent. The odds ratio for the evaluation of QPM vs. conventional maize for aroma, for example, equals exp (1.9) = 6.9, indicating that the odds of QPM having a higher score for aroma is nearly seven times higher than the odds of conventional maize having a higher score. Similarly, the odds of QPM having a higher score for texture in hand is three (the exponent of 1.1) times higher than the odds for CM. The results of the ordinal regression, as derived from the sign, size and significance of the coefficients, are very similar to those of comparing the means. 
Table 3. Consumer acceptance of QPM in Tanzania (short mixed effect ordinal model, dependent variable is a 9-point Likert scale)

\begin{tabular}{|c|c|c|c|c|c|c|c|c|c|c|c|c|c|c|c|}
\hline Analysis & Variable & Coeff. & St. err. & Coeff. & St. err. & & Coeff. & St. err. & Coeff. & St. err. & Coeff. & St. err. & & Coeff. & $\begin{array}{l}\text { St. } \\
\text { err. }\end{array}$ \\
\hline \multirow{2}{*}{$\begin{array}{l}\text { Comparing } \\
\text { means }\end{array}$} & $\mathrm{QPM}$ & 7.27 & 0.13 & 7.23 & 0.15 & & 7.40 & 0.16 & 7.63 & 0.20 & 7.67 & 0.20 & & 7.60 & 0.16 \\
\hline & $\begin{array}{l}\text { Difference QPM - } \\
\mathrm{CM}\end{array}$ & 0.33 & & 0.87 & & **** & 0.53 & $*$ & 1.33 & $* * *$ & 1.40 & & **** & 1.13 & $*$ \\
\hline \multirow{2}{*}{$\begin{array}{l}\text { Ordinal } \\
\text { regression }\end{array}$} & QPM & 0.78 & 0.51 & 1.90 & 0.55 & $* *$ & 1.15 & 0.50 & 2.01 & $0.53^{* * *}$ & 1.96 & 0.53 & $* * *$ & 1.93 & $0.54^{* *}$ \\
\hline & $\begin{array}{l}\text { Order (presented } \\
\text { first) }\end{array}$ & -0.07 & 0.49 & -0.57 & 0.49 & & 0.50 & 0.48 & -0.11 & 0.47 & -0.09 & 0.48 & & 0.46 & 0.47 \\
\hline
\end{tabular}

${ }^{1}$ Variance of random subject effect estimated at zero

2 -2 Log likelihood

$\mathrm{SE}=$ standard error, $\mathrm{QPM}=$ quality protein maize, $\mathrm{CM}=$ conventional maize

$* * *, * *, *$ : significant at $0.1 \%, 1 \%$, and $5 \%$, respectively 
To test for the possible effect of the order of presentation, a binary variable was included to indicate if the product was presented first (order $=1$ ) or second (order $=0$ ), but the coefficient was not found significant, indicating that the order of presentation did not affect consumers' acceptance of the food samples. Because only one QPM and one CM variety was included, the observed preference may be variety-specific and may not necessarily be attributable to the quality protein trait. We can conclude, however, this QPM variety is accepted and even preferred for most traits over this conventional maize variety for the preparation of ugali.

To analyze other factors that might influence consumer acceptance, the long model of Equation 4 was estimated, containing both direct effects and cross effects (Table 4). In the direct effects, the QPM variety has a significant positive effect for texture in hand, texture in mouth, and taste. The other significant direct effects were gender and education on appearance, indicating that women generally scored the ugali lower for appearance, as did participants with higher education.

The interpretation of the direct effects in a model with cross effects depends on the significance of the latter. Because the cross effect QPM x female is not significant, the direct effect of gender relates to both QPM and CM. But since the cross effect of QPM x education is significant and positive, the direct negative effect of education only applies to the reference category, conventional maize. So with increasing education, the odds that a respondent favorably rates the appearance of conventional maize decrease. To analyze the relationship between QPM and education, we have to add the direct effect (-0.35) to the cross effect $(+0.34)$ and that sum is not significantly different from zero, indicating that acceptance of QPM's appearance does not vary with education.

We conclude that participants in Tanzania scored the QPM ugali higher than CM ugali overall and for all specific characteristics. Consumer demographics played only a minor role: only education and gender had a significant effect, and then only on acceptance of appearance.

\section{Kenya}

In Kenya, two QPM varieties, KH631Q and WSQ104, were compared to two conventional varieties, EMCO and H513, in one urban and two rural settings, on a five-point scale. Despite the less precise scale, the answers were much better distributed than in 
Table 4. Consumer acceptance of QPM in Tanzania (long mixed effect ordinal model, dependent variable is a 9-point Likert scale)

\begin{tabular}{|c|c|c|c|c|c|c|c|c|c|c|c|c|c|}
\hline \multirow[t]{2}{*}{ Group } & \multirow[t]{2}{*}{ Variable } & \multicolumn{2}{|c|}{ Appearance } & \multicolumn{2}{|c|}{ Aroma } & \multicolumn{2}{|c|}{ Texture in Hand } & \multicolumn{2}{|c|}{$\begin{array}{l}\text { Texture in } \\
\text { Mouth }\end{array}$} & \multicolumn{2}{|c|}{ Taste $^{1}$} & \multicolumn{2}{|c|}{ Overall } \\
\hline & & Coeff. & $\mathrm{SE}$ & Coeff. & $\mathrm{SE}$ & Coeff. & $\mathrm{SE}$ & Coeff. & $\mathrm{SE}$ & Coeff. & $\mathrm{SE}$ & Coeff. & $\mathrm{SE}$ \\
\hline \multirow[t]{5}{*}{$\begin{array}{l}\text { Direct } \\
\text { effects }\end{array}$} & QPM & 0.00 & 2.77 & 2.78 & 2.72 & 6.00 & $2.79^{*}$ & 7.30 & $2.76^{*}$ & 6.45 & $3.04^{*}$ & 1.86 & 2.61 \\
\hline & Female & -2.25 & $1.01^{*}$ & -1.50 & 0.89 & 0.71 & 0.96 & -0.68 & 0.80 & -0.19 & 0.79 & -0.37 & 0.80 \\
\hline & Age (years) & 0.06 & 0.05 & -0.02 & 0.05 & 0.09 & 0.05 & 0.07 & 0.04 & 0.04 & 0.04 & 0.05 & 0.04 \\
\hline & Education (years) & -0.35 & $0.11^{* *}$ & -0.06 & 0.09 & -0.13 & 0.10 & -0.04 & 0.08 & -0.08 & 0.08 & -0.12 & 0.08 \\
\hline & $\begin{array}{l}\text { Order (presented } \\
\text { first) }\end{array}$ & 0.37 & 0.54 & -0.27 & 0.52 & 0.77 & 0.53 & 0.40 & 0.51 & 0.40 & 0.52 & 0.97 & 0.52 \\
\hline \multirow[t]{3}{*}{$\begin{array}{l}\text { Cross } \\
\text { effects }\end{array}$} & QPM x female & 1.83 & 1.23 & 1.59 & 1.19 & 0.50 & 1.18 & 1.90 & 1.17 & 1.54 & 1.13 & 2.26 & 1.18 \\
\hline & QPM $x$ age & -0.12 & 0.07 & -0.03 & 0.06 & -0.08 & 0.06 & -0.11 & 0.06 & -0.08 & 0.06 & -0.05 & 0.06 \\
\hline & QPM x education & 0.34 & $0.13^{*}$ & 0.01 & 0.12 & -0.11 & 0.12 & -0.07 & 0.11 & -0.08 & 0.12 & 0.09 & 0.11 \\
\hline \multirow[t]{2}{*}{ Model } & $\begin{array}{l}\text {-2 Residual log } \\
\text { pseudo-likelihood }\end{array}$ & 985 & & 999 & & 955 & & 1484 & & $155^{2}$ & & 1466 & \\
\hline & $\mathrm{N}$ & 60 & & 60 & & 60 & & 60 & & 59 & & 60 & \\
\hline
\end{tabular}

\footnotetext{
${ }^{1}$ Variance of random subject effect estimated at zero.

2 -2 Log likelihood

$\mathrm{SE}=$ standard error, $\mathrm{QPM}=$ quality protein maize, $\mathrm{CM}=$ conventional maize

$* * *, * *, *$ : significant at $0.1 \%, 1 \%$, and $5 \%$, respectively
} 
Tanzania where a nine-point scale was used. The categories with the highest number of answers were "good" (36\%) and "fair" (33\%), but evaluations were also received for the extremes "very poor" (4\%) and "very good" (11\%).

Because of the clear ordinal nature of the evaluation, only ordinal regression was used for the analysis. The results of the short model of Equation 3 show that one QPM variety, KH631Q, was more appreciated than H513 (the omitted class in the regression), for taste, but otherwise there were no significant differences between the two (Table 5). The other QPM variety, WSQ104, was more appreciated than H513 for appearance, texture and overall, but there was no difference for taste. Further, there were no significant differences between the two conventional varieties. The QPM varieties were never rated lower than CM varieties in one-on-one comparisons for any of the four criteria. However, there does not seem to be a systematic pattern in the acceptance of the two QPM varieties compared with the two CM varieties. This suggests that the greater acceptance of WSQ104 in general and KH631Q for taste may be due to characteristics specific to one or both of those varieties and may not be attributable to the quality protein trait. Regardless, the equal or greater preference of these varieties among Kenyan consumers indicates that these or related QPM varieties that also have good agronomic performance could be accepted and utilized in this target population.

The short model included binary variables for location and order. The location did not have a significant effect on consumer evaluation, except for the overall evaluation in one site, Mukuria, but order often did. For all criteria except appearance (for which all food samples could be evaluated simultaneously), consumers were likely to give higher acceptance ratings to those food samples that were evaluated first. As they did more evaluations, however, they became more critical and their scores decreased. This clearly illustrates the need to present food samples in random order in consumer acceptance studies.

To estimate the effect of demographic and educational variables, the long model with cross effects (Equation 4) was estimated. The results of the long model show effects of location, gender, age and education, but only for one variety, KH613Q (Table 6). This variety, compared to the control H513, is less appreciated in Itabua for appearance, texture and taste. This variety is, however, more appreciated by women in the overall evaluation, and more appreciated by older and more educated consumers in taste and overall evaluation. 
Table 5. Consumer acceptance of QPM in Kenya (short mixed effect ordinal model, dependent variable is a 5-point Likert scale)

\begin{tabular}{|c|c|c|c|c|c|c|c|c|c|c|c|c|c|}
\hline \multirow[b]{2}{*}{ Variable } & \multirow[b]{2}{*}{ Values } & \multicolumn{3}{|c|}{ Appearance } & \multicolumn{3}{|c|}{ Texture $^{1}$} & \multicolumn{3}{|c|}{ Taste } & \multicolumn{3}{|c|}{ Overall } \\
\hline & & Coeff. & Std Err. & & Coeff. & Std Err. & & Coeff. & Std Err. & & Coeff. & $\begin{array}{l}\text { Std } \\
\text { Err. }\end{array}$ & \\
\hline \multirow{4}{*}{$\begin{array}{c}\text { Variety (ZH513 } \\
\text { is the reference } \\
\text { category) }\end{array}$} & $\mathrm{EMCO}(\mathrm{CM})$ & 0.45 & 0.23 & & 0.38 & 0.22 & & 0.29 & 0.23 & & 0.27 & 0.23 & \\
\hline & KH631Q (QPM) & -0.01 & 0.23 & & 0.40 & 0.23 & & 0.52 & 0.23 & $*$ & 0.22 & 0.23 & \\
\hline & WSQ104 (QPM) & 0.61 & 0.23 & $* *$ & 0.71 & 0.24 & $* *$ & 0.37 & 0.23 & & 0.47 & 0.23 & $*$ \\
\hline & H513 (CM) & & & & & & & & & & & & \\
\hline \multirow{3}{*}{$\begin{array}{l}\text { Location (Embu } \\
\text { is reference } \\
\text { category) }\end{array}$} & Itabua (rural women) & -0.26 & 0.28 & & -0.07 & 0.23 & & 0.01 & 0.27 & & -0.34 & 0.26 & \\
\hline & Mukuria (rural mixed) & -0.17 & 0.22 & & -0.03 & 0.18 & & -0.09 & 0.21 & & -0.43 & 0.20 & $*$ \\
\hline & Embu (urban) & & & & & & & & & & & & \\
\hline \multirow{4}{*}{$\begin{array}{l}\text { Order of } \\
\text { evaluation (4th is } \\
\text { the reference } \\
\text { category) }\end{array}$} & $1^{\text {st }}$ & 0.32 & 0.23 & & 0.51 & 0.23 & $*$ & 0.54 & 0.23 & $*$ & 0.61 & 0.23 & $* *$ \\
\hline & $2^{\text {nd }}$ & 0.02 & 0.23 & & 0.46 & 0.23 & $*$ & 0.11 & 0.22 & & 0.15 & 0.23 & \\
\hline & $3^{\text {rd }}$ & 0.22 & 0.23 & & 0.39 & 0.23 & & 0.27 & 0.23 & & 0.27 & 0.23 & \\
\hline & $4^{\text {th }}$ & & & & & & & & & & & & \\
\hline \multirow[t]{2}{*}{ Model } & $\begin{array}{l}\text {-2 Residual log } \\
\text { pseudo-likelihood }\end{array}$ & 7483 & & & 1460 & 2 & & 6924 & & & 7267 & & \\
\hline & $\mathrm{n}$ & 514 & & & 510 & & & 516 & & & 505 & & \\
\hline
\end{tabular}

${ }^{1}$ Variance of random subject effect estimated at zero

2 -2 Log likelihood

$\mathrm{SE}=$ Standard error, $\mathrm{QPM}=$ quality protein maize, $\mathrm{CM}=$ conventional maize

***, **,*: significant at $0.1 \%, 1 \%$, and $5 \%$, respectively 
Table 6. Consumer acceptance of QPM in Kenya (long mixed effect ordinal model, dependent variable is a 5point Likert scale)

\begin{tabular}{|c|c|c|c|c|c|c|c|c|c|}
\hline \multirow[b]{2}{*}{ Variable } & \multirow[b]{2}{*}{ Values } & \multicolumn{2}{|c|}{ Appearance } & \multicolumn{2}{|c|}{ Texture $^{1}$} & \multicolumn{2}{|l|}{ Taste } & \multicolumn{2}{|l|}{ Overall } \\
\hline & & Coeff. & SE & Coeff. & SE & $\overline{\text { Coeff. }}$ & $\mathrm{SE}$ & Coeff. & SE \\
\hline \multirow{3}{*}{$\begin{array}{l}\text { Variety } \\
\text { (H513 is the reference } \\
\text { category) }\end{array}$} & EMCO & 0.24 & 1.61 & 0.59 & 1.62 & 0.02 & 1.57 & 0.23 & 1.62 \\
\hline & KH631Q & 0.82 & 1.61 & -1.42 & 1.62 & -3.76 & $1.54 *$ & -4.80 & $1.60 * *$ \\
\hline & WSQ104 & 1.22 & 1.62 & -2.85 & 1.73 & -0.14 & 1.54 & -1.97 & 1.60 \\
\hline \multirow{2}{*}{$\begin{array}{l}\text { Location } \\
\text { (Embu is reference } \\
\text { category) }\end{array}$} & Itabua & 0.31 & 0.59 & 0.46 & 0.56 & 0.56 & 0.57 & -0.14 & 0.58 \\
\hline & Mukuria & -0.57 & 0.54 & -0.45 & 0.50 & 0.16 & 0.52 & -0.64 & 0.52 \\
\hline \multirow{3}{*}{$\begin{array}{l}\text { Order } \\
(4 \text { is the reference } \\
\text { category) }\end{array}$} & 1 & 0.50 & 0.26 & 0.58 & $0.25 *$ & 0.53 & $0.25 *$ & 0.66 & $0.26 *$ \\
\hline & 2 & -0.02 & 0.25 & 0.55 & $0.25 *$ & 0.15 & 0.25 & 0.12 & 0.25 \\
\hline & 3 & 0.15 & 0.25 & 0.34 & 0.25 & 0.19 & 0.25 & 0.19 & 0.25 \\
\hline Female & & 0.04 & 0.52 & -0.35 & 0.49 & -0.69 & 0.49 & -0.59 & 0.51 \\
\hline Age (years) & & 0.01 & 0.02 & 0.00 & 0.02 & -0.01 & 0.02 & -0.01 & 0.02 \\
\hline Education (years) & & -0.03 & 0.06 & -0.04 & 0.06 & -0.06 & 0.06 & -0.11 & 0.06 \\
\hline \multirow{6}{*}{$\begin{array}{l}\text { Variety*location } \\
\text { (H513 and Embu are the } \\
\text { references) }\end{array}$} & EMCO x Itabua & -0.84 & 0.79 & -0.29 & 0.77 & -0.86 & 0.77 & -0.34 & 0.79 \\
\hline & KH631Q x Itabua & -1.82 & $0.79 *$ & -1.80 & $0.78 *$ & -1.54 & $0.77 *$ & -0.85 & 0.79 \\
\hline & WSQ104 x Itabua & 0.70 & 0.79 & -0.21 & 0.81 & -0.68 & 0.77 & 0.38 & 0.80 \\
\hline & EMCO x Mukuria & 0.21 & 0.73 & 0.63 & 0.69 & -0.77 & 0.69 & 0.35 & 0.71 \\
\hline & KH631Q x Mukuria & 0.14 & 0.72 & -0.16 & 0.69 & 0.02 & 0.70 & 0.29 & 0.72 \\
\hline & WSQ104 x Mukuria & 0.40 & 0.71 & 0.48 & 0.73 & -0.78 & 0.70 & 0.09 & 0.72 \\
\hline \multirow{3}{*}{$\begin{array}{l}\text { Variety*sex } \\
\text { (H513 and male are the } \\
\text { references) }\end{array}$} & EMCO x Female & -0.10 & 0.68 & -0.05 & 0.67 & 0.30 & 0.66 & -0.09 & 0.69 \\
\hline & KH631Q x Female & 0.22 & 0.68 & 0.99 & 0.68 & 1.25 & 0.67 & 1.53 & $0.69 *$ \\
\hline & WSQ104 x Female & 0.65 & 0.69 & 1.57 & $0.71 *$ & 0.74 & 0.67 & 0.80 & 0.69 \\
\hline Variety*age & EMCO x Age & 0.00 & 0.02 & -0.02 & 0.02 & 0.00 & 0.02 & -0.01 & 0.02 \\
\hline \multirow[t]{2}{*}{ (H513 is the reference) } & KH631Q x Age & -0.02 & 0.02 & 0.01 & 0.02 & 0.04 & $0.02 *$ & 0.04 & $0.02 *$ \\
\hline & WSQ104 x Age & -0.03 & 0.02 & 0.03 & 0.02 & 0.01 & 0.02 & 0.01 & 0.02 \\
\hline Variety*education & EMCO $x$ Education & 0.04 & 0.08 & 0.00 & 0.08 & 0.04 & 0.08 & 0.02 & 0.08 \\
\hline \multirow[t]{2}{*}{ (H513 is the reference) } & $\begin{array}{l}\text { KH631Q x } \\
\text { Education }\end{array}$ & 0.01 & 0.08 & 0.09 & 0.08 & 0.21 & $0.08 * *$ & 0.22 & $0.08 * *$ \\
\hline & $\begin{array}{l}\text { WSQ104 x } \\
\text { Education }\end{array}$ & -0.01 & 0.08 & 0.10 & 0.08 & 0.01 & 0.08 & 0.13 & 0.08 \\
\hline \multirow[t]{2}{*}{ Model } & $\begin{array}{l}\text {-2 Residual log } \\
\text { pseudo-likelihood }\end{array}$ & 6773 & & $1254^{2}$ & & 6135 & & 6371 & \\
\hline & $\mathrm{N}$ & 447 & & 442 & & 448 & & 437 & \\
\hline \multicolumn{10}{|c|}{${ }^{1}$ Variance of random subject effect estimated at zero } \\
\hline \multicolumn{10}{|l|}{${ }^{2}-2$ Log likelihood } \\
\hline $\mathrm{SE}=$ Standard error, $\mathrm{QP}$ & $=$ quality protein $\mathrm{ms}$ & $\mathrm{CM}$ & onv & nal ma & ize & & & & \\
\hline sign & 707 and 507 & ively & & & & & & & \\
\hline
\end{tabular}

We conclude that among the urban and rural consumers of Embu District, QPM did not have any negative preferences, and that one QPM variety was generally better accepted 
over the two conventional varieties. The individual characteristics of varieties matter, however, and they differ between sites and with the socioeconomic characteristics of the consumers.

\section{Ethiopia}

In Ethiopia, the 5-point scale was used, and the distribution of the scores was similar to that of Kenya. The scores with the highest proportion of responses were also "good" (30\%) and "fair" (36\%), with a similar proportion of "very poor" $(4 \%)$, although a substantially higher proportion of "very good" (24\%). This distribution was similar across all criteria.

The results of the short ordinal regression show that Ethiopian consumers had a strong preference for injera made from teff, as indicated by the large and significant drop in acceptance when maize was mixed in the dough (Table 7). This drop was measured by the coefficient of the binary variable "maize", indicating the use of a maize-teff mixture as compared injera from pure teff, and was significant for all criteria, including overall evaluation, and was independent of the maize proportion, either $50 \%$ or $80 \%$ (with $50 \%$ being the reference category). There was a substantial difference between the conventional varieties, however, with BH540 scoring significantly better than Melkassa 2 on all criteria, as shown by the significant coefficients for the variable BH540 and to be interpreted as the difference with the reference category for maize, Melkassa 2.

When QPM instead of conventional maize is substituted for teff, the drop in acceptance is less pronounced, as the significant coefficient for QPM shows. There is, however, a big difference between the two QPM varieties, and BHQP542 is substantially more appreciated than Melkassa 6Q. The last variety's scores are actually similar to those of BH540. On the order of presentation, the results show that acceptance scores were significantly higher in the first round than in the second round for the first two criteria of the evaluation, appearance and aroma. They were not significant for the other criteria, or for the order of presentation within the rounds. Still, it illustrates the importance of presenting food samples in random order.

To assess the effect of consumer demographics, those were added as factors in the long model (Table 8). The additional factors altered slightly the coefficient on the products, but not in a major way, and direct effects in a model with cross effects need to be interpreted carefully, as discussed above. The results of the long model show that consumers with greater education are more critical in their evaluation: their scores are generally lower, as indicated 
Table 7. Consumer acceptance of QPM in Ethiopia (short mixed effect ordinal model, dependent variable is a 5-point Likert scale, the general reference category is teff, within the mixtures it is $50 \%$ maize, within conventional maize it is Melkassa2, and within QPM it is Melkassa6Q)

\begin{tabular}{|c|c|c|c|c|c|c|c|c|c|c|c|c|c|c|}
\hline \multirow[t]{2}{*}{ Values } & \multicolumn{2}{|c|}{ Appearance } & \multicolumn{2}{|c|}{ Aroma } & \multicolumn{2}{|c|}{ Pliability } & \multicolumn{2}{|c|}{ Texture in Hand } & \multicolumn{2}{|c|}{$\begin{array}{l}\text { Texture in } \\
\text { Mouth }\end{array}$} & \multicolumn{2}{|c|}{ Taste } & \multicolumn{2}{|c|}{ Overall } \\
\hline & Coeff. & Std err. & Coeff. & Std err. & Coeff. & $\begin{array}{l}\text { Std } \\
\text { err. }\end{array}$ & Coeff. & Std err. & Coeff. & Std err. & Coeff. & Std err. & Coeff. & err. \\
\hline Maize & -3.70 & $0.24^{* * * *}$ & -4.24 & $0.25^{* * * *}$ & -5.74 & $0.29^{* * * *}$ & -6.01 & $0.29^{* * * *}$ & -5.26 & $0.27^{* * * *}$ & -5.31 & $0.27^{\text {**** }}$ & -5.9 & $0.3^{* * * *}$ \\
\hline BH540 & 1.20 & $0.24^{* * * *}$ & 0.73 & $0.24^{* *}$ & 0.93 & $0.24^{* * * *}$ & 1.39 & $0.25^{* * * *}$ & 0.54 & $0.24^{*}$ & 1.08 & $0.24^{\text {**** }}$ & 0.8 & $0.2^{* * * *}$ \\
\hline Maize at $80 \%$ & 0.43 & 0.24 & -0.08 & 0.24 & -0.19 & 0.24 & 0.07 & 0.24 & 0.15 & 0.24 & 0.19 & 0.24 & 0.0 & 0.2 \\
\hline BH540 at $80 \%$ & -0.05 & 0.34 & 0.00 & 0.34 & 0.52 & 0.34 & 0.25 & 0.34 & -0.02 & 0.34 & -0.19 & 0.34 & 0.3 & 0.3 \\
\hline QPM & 0.31 & 0.24 & 0.49 & $0.24^{*}$ & 0.77 & $0.24^{* * *}$ & 0.87 & $0.24^{* * * *}$ & 0.66 & $0.24^{* *}$ & 0.77 & $0.24^{* *}$ & 0.7 & $0.2^{* *}$ \\
\hline BHQP542 & 1.41 & $0.24^{* * * *}$ & 1.40 & $0.25^{* * * *}$ & 1.73 & $0.25^{* * * *}$ & 2.07 & $0.25^{* * * *}$ & 1.70 & $0.25^{\text {***** }}$ & 1.40 & $0.25^{* * * *}$ & 2.1 & $0.3^{* * * *}$ \\
\hline QPM at $80 \%$ & -0.37 & 0.34 & 0.04 & 0.34 & -0.13 & 0.34 & -0.30 & 0.34 & 0.03 & 0.34 & -0.26 & 0.34 & -0.1 & 0.3 \\
\hline BHQP542 at $80 \%$ & -0.26 & 0.34 & 0.27 & 0.35 & 0.14 & 0.35 & -0.12 & 0.35 & -0.58 & 0.34 & -0.11 & 0.34 & -0.5 & 0.4 \\
\hline 1 & 0.28 & $0.11^{*}$ & 0.31 & $0.11^{* *}$ & 0.10 & 0.12 & 0.22 & 0.12 & 0.19 & 0.11 & 0.18 & 0.11 & 0.1 & 0.1 \\
\hline 1 & 0.03 & 0.18 & -0.11 & 0.18 & 0.24 & 0.18 & 0.31 & 0.18 & -0.02 & 0.18 & -0.16 & 0.18 & 0.0 & 0.2 \\
\hline 2 & 0.07 & 0.18 & -0.05 & 0.18 & -0.14 & 0.18 & 0.13 & 0.18 & -0.04 & 0.18 & -0.01 & 0.18 & 0.1 & 0.2 \\
\hline 3 & -0.06 & 0.17 & 0.08 & 0.18 & 0.13 & 0.18 & 0.16 & 0.18 & 0.07 & 0.18 & -0.03 & 0.18 & 0.1 & 0.2 \\
\hline 4 & 0.03 & 0.18 & 0.07 & 0.18 & 0.05 & 0.18 & 0.15 & 0.18 & 0.04 & 0.18 & 0.04 & 0.18 & 0.0 & 0.2 \\
\hline $\begin{array}{l}\text {-2 Residual log } \\
\text { pseudo-likelihood }\end{array}$ & 20760 & & 22991 & & 40039 & & 30661 & & 20784 & & 27754 & & 24895 & \\
\hline $\mathrm{N}$ & 1199 & & 1200 & & 1200 & & 1200 & & 1200 & & 1199 & & 1200 & \\
\hline
\end{tabular}

${ }^{1}$ Variance of random subject effect estimated at zero

2 -2 Log likelihood

$\mathrm{SE}=$ Standard error, $\mathrm{QPM}=$ quality protein maize, $\mathrm{CM}=$ conventional maize

$* * *, * * *$ : significant at $0.1 \%, 1 \%$, and $5 \%$, respectively 
Table 8. Consumer acceptance of QPM in Ethiopia (long mixed effect ordinal model, dependent variable is a 5-point Likert scale)

\begin{tabular}{|c|c|c|c|c|c|c|c|c|c|c|c|c|}
\hline \multirow[b]{2}{*}{ Variable } & \multirow[b]{2}{*}{ Values } & \multicolumn{2}{|c|}{ Appearance } & Aroma & \multicolumn{2}{|c|}{ Pliability } & \multicolumn{2}{|c|}{ Texture in Hand } & \multicolumn{2}{|c|}{ Texture in Mouth } & \multirow{2}{*}{$\begin{array}{c}\text { Taste } \\
\text { Coeff. SE }\end{array}$} & \multirow{2}{*}{$\begin{array}{r}\text { Overall } \\
\text { Coeff. SE } \\
\end{array}$} \\
\hline & & Coeff. & SE & Coeff. SE & Coeff. & SE & Coeff. & SE & Coeff. & SE & & \\
\hline \multirow{4}{*}{$\begin{array}{l}\text { Maize } \\
\text { (Melkassa } 2 \text { is the } \\
\text { reference) }\end{array}$} & Maize & -3.74 & $0.24^{* * * *}$ & $-4.280 .25^{* * * *}$ & -5.79 & $0.29^{* * * * *}$ & -6.07 & $0.29^{* * * *}$ & -5.31 & $0.27^{* * * *}$ & $-5.360 .27^{* * * * *}$ & $-5.40 .3^{* * * *}$ \\
\hline & BH540 & 1.22 & $0.24^{* * * *}$ & $0.730 .24^{* * *}$ & 0.94 & $0.24^{* * * *}$ & 1.41 & $0.25^{\text {***** }}$ & 0.55 & $0.24^{*}$ & $1.090 .24^{* * * *}$ & $1.10 .2^{* * * *}$ \\
\hline & Maize at $80 \%$ & 0.44 & 0.24 & -0.090 .24 & -0.21 & 0.24 & 0.07 & 0.24 & 0.15 & 0.24 & 0.190 .24 & 0.20 .2 \\
\hline & BH540 at $80 \%$ & -0.06 & 0.34 & 0.010 .34 & 0.53 & 0.34 & 0.25 & 0.35 & -0.03 & 0.34 & -0.190 .34 & -0.20 .3 \\
\hline \multirow{4}{*}{$\begin{array}{l}\text { QPM } \\
\text { (Melkassa 6Q is the } \\
\text { reference) }\end{array}$} & QPM & -1.16 & $0.58^{*}$ & 0.900 .59 & 1.34 & $0.60^{*}$ & 0.33 & 0.60 & 0.65 & 0.59 & 0.360 .59 & 0.40 .6 \\
\hline & BHQP542 & 1.43 & $0.24^{* * * *}$ & $1.400 .25^{* * * *}$ & 1.74 & $0.25^{* * *}$ & 2.08 & $0.25^{* * * *}$ & 1.71 & $0.25^{* * * *}$ & $1.400 .25^{* * *}$ & $1.40 .2^{* * * *}$ \\
\hline & QPM at $80 \%$ & -0.40 & 0.34 & 0.050 .34 & -0.11 & 0.34 & -0.30 & 0.34 & 0.03 & 0.34 & -0.260 .34 & -0.30 .3 \\
\hline & $\begin{array}{l}\text { BHQP542 at } \\
80 \%\end{array}$ & -0.24 & 0.34 & 0.270 .35 & 0.14 & 0.35 & -0.12 & 0.35 & -0.59 & 0.34 & $-0.11 \quad 0.34$ & -0.10 .3 \\
\hline \multirow{5}{*}{$\begin{array}{l}\text { Round } \\
\text { Order of presentation }\end{array}$} & 1 & 0.27 & $0.11^{*}$ & $0.330 .11^{\text {*** }}$ & 0.11 & 0.12 & 0.23 & $0.12^{*}$ & 0.20 & 0.11 & 0.180 .11 & 0.20 .1 \\
\hline & 1 & 0.01 & 0.18 & -0.140 .18 & 0.23 & 0.18 & 0.29 & 0.18 & -0.04 & 0.18 & -0.190 .18 & $\begin{array}{ll}-0.2 & 0.2\end{array}$ \\
\hline & 2 & 0.06 & 0.18 & -0.070 .18 & -0.16 & 0.18 & 0.11 & 0.18 & -0.06 & 0.18 & -0.020 .18 & $\begin{array}{ll}0.0 & 0.2\end{array}$ \\
\hline & 3 & -0.07 & 0.18 & 0.100 .18 & 0.15 & 0.18 & 0.17 & 0.18 & 0.08 & 0.18 & -0.040 .18 & $\begin{array}{ll}0.0 & 0.2\end{array}$ \\
\hline & 4 & -0.01 & 0.18 & 0.050 .18 & 0.05 & 0.18 & 0.13 & 0.18 & 0.02 & 0.18 & 0.010 .18 & $\begin{array}{ll}0.0 & 0.2\end{array}$ \\
\hline Sex & Female & 0.10 & 0.24 & 0.410 .27 & -0.10 & 0.27 & -0.12 & 0.29 & -0.01 & 0.28 & 0.110 .31 & $\begin{array}{ll}0.1 & 0.3 \\
\end{array}$ \\
\hline Age (years) & & 0.01 & 0.01 & 0.010 .01 & 0.02 & 0.01 & 0.02 & 0.01 & 0.02 & 0.01 & 0.010 .02 & $\begin{array}{ll}0.0 & 0.0 \\
\end{array}$ \\
\hline Education (years) & & -0.04 & $0.02 *$ & $-0.080 .02^{\text {*** }}$ & -0.05 & $0.02^{*}$ & -0.06 & $0.03^{*}$ & -0.07 & $0.02^{* *}$ & $-0.080 .03^{* *}$ & $-0.10 .0^{* * * *}$ \\
\hline \multirow[t]{3}{*}{ Interactions } & $\mathrm{QPM}^{*}$ female & -0.10 & 0.23 & -0.070 .23 & -0.03 & 0.24 & 0.06 & 0.24 & -0.18 & 0.23 & $\begin{array}{ll}-0.36 & 0.23\end{array}$ & $-0.4 \quad 0.2$ \\
\hline & QPM*age & 0.03 & $0.01 *$ & -0.020 .01 & -0.02 & 0.01 & 0.00 & 0.01 & 0.00 & 0.01 & 0.010 .01 & $\begin{array}{ll}0.0 & 0.0\end{array}$ \\
\hline & QPM*education & 0.05 & $0.02 *$ & 0.020 .02 & 0.01 & 0.02 & 0.04 & $0.02 *$ & 0.02 & 0.02 & $0.03 \quad 0.02$ & 0.00 .0 ** \\
\hline \multirow[t]{2}{*}{ Model } & $\begin{array}{l}\text {-2 Residual log } \\
\text { pseudo-llhood }\end{array}$ & 21045 & & 23454 & 43955 & & 30990 & & 20934 & & 27836 & 25261 \\
\hline & $\mathrm{N}$ & 1199 & & 1200 & 1200 & & 1200 & & 1200 & & 1199 & 1200 \\
\hline
\end{tabular}

***, ****: significant at $0.1 \%, 1 \%$, and $5 \%$, respectively, $\mathrm{SE}=$ Standard error, $\mathrm{QPM}=$ quality protein maize, $\mathrm{CM}=$ conventional maize 
by the negative coefficients. On the other hand, more educated participants have a slightly higher score for QPM varieties. Gender and age, on the other hand, did not show any significant effect on the sensory evaluation.

\section{Factors affecting overall evaluation}

Overall scores were analyzed by regressing the scores of the different criteria on the overall score, using a separate linear regression model for each country (Table 9). The value of a coefficient for a criterion can be interpreted as the contribution of the evaluation for that criterion to the overall evaluation. The results show that all evaluated sensory characteristics contributed to the overall evaluation, except for aroma and appearance of ugali in Tanzania. These last results are, however, likely affected by the small sample size.

Table 9. Effect of the scores for specific criteria on the overall evaluation score (using ordinary least squares regression)

\begin{tabular}{|c|c|c|c|c|c|c|c|c|c|}
\hline \multirow[b]{2}{*}{ Criteria } & \multicolumn{3}{|c|}{ Tanzania (ugali) } & \multicolumn{3}{|c|}{ Kenya (githeri) } & \multicolumn{3}{|c|}{ Ethiopia (injera) } \\
\hline & Coeff. & SE & & Coeff. & SE & & Coeff. & SE & \\
\hline (Intercept) & 0.03 & 0.82 & & 0.49 & 0.12 & $* * *$ & 0.20 & 0.06 & $* * *$ \\
\hline Appearance & -0.02 & 0.10 & & 0.28 & 0.04 & $* * *$ & 0.09 & 0.02 & $* * *$ \\
\hline Aroma & 0.17 & 0.11 & & - & - & & 0.10 & 0.02 & $* * *$ \\
\hline Pliability & - & - & & - & - & & 0.16 & 0.02 & $* * *$ \\
\hline Texture & - & - & & 0.34 & 0.03 & $* * *$ & - & - & \\
\hline Texture in hand & 0.24 & 0.11 & $* *$ & - & - & & 0.15 & 0.03 & $* * *$ \\
\hline Texture in mouth & 0.19 & 0.10 & & - & - & & 0.15 & 0.03 & $* * *$ \\
\hline Taste & 0.43 & 0.10 & $* * *$ & 0.26 & 0.03 & $* * *$ & 0.34 & 0.02 & $* * *$ \\
\hline $\mathrm{R}^{2}$ & 0.74 & & & 0.57 & & & 0.79 & & \\
\hline $\mathrm{N}$ & 60 & & & 485 & & & 1198 & & \\
\hline
\end{tabular}

Taste and texture were important to overall acceptance in all three countries, with taste being the biggest contributor to acceptance in Tanzania (0.43) and Ethiopia (0.34). In Kenya, taste was also important $(0.26)$, but texture $(0.34)$ and appearance $(0.28)$ were more important. Appearance is important because githeri is a mixture of boiled maize and beans, and the maize kernels are clearly visible.

In Ethiopia, all other criteria apart from taste made a significant contribution to the overall acceptance, but the coefficients were relatively small, between 0.09 and 0.16 . Here, the second most important criteria after taste was pliability (0.16), which is important because 
the injera is folded and used as a spoon to take the rest of the food to the mouth. This also explains why texture in both hand and mouth are the next most important criteria (0.15).

\section{DISCUSSION}

This study used a rigorous methodology to evaluate the acceptability of sensory characteristics of QPM varieties when used to prepare foods common in East African diets. The food products evaluated were ugali, a stiff porridge made from maize flour, in Tanzania; githeri, a mixture of boiled maize and beans, in Kenya; and injera, a pancake-like preparation made from fermented dough of teff flour, often mixed with maize or other cereals, in Ethiopia. The products were evaluated by urban, rural, male, and female consumers with varying levels of education. The study established that African consumers can distinguish QPM products from their conventional counterparts in double-blind evaluations, contrary to conventional wisdom, and these distinct sensory characteristics should be acknowledged in promotion and dissemination activities. While early experience with opaque- 2 maize led to a widely-held belief that any difference in the sensory characteristics of these biofortified varieties would lead to their rejection by consumers, this study indicates that the quality protein trait can result in sensory changes that are preferred by consumers in East Africa.

In all three countries, consumers found QPM acceptable and even preferable to conventional maize for the preparation of widely-consumed foods. This indicates that if QPM grain were accessible, it could be widely used by consumers, enabling the biofortified crop to have a positive impact in at-risk populations, in particular those with poor quality protein intakes and lysine deficiency, commonly associated with cereal-based diets ${ }^{42}$. The study did, however, find substantial differences in consumer acceptance among maize varieties, between conventional and QPM varieties as well as between varieties within each group. It is, therefore, important to have new varieties carefully tested by consumers, and to avoid overgeneralization. Furthermore, as impact is determined by both farmer adoption and consumer acceptance, QPM varieties must have competitive agronomic as well as consumer characteristics.

In Tanzania, only one QPM and one conventional variety were evaluated, in an urban setting, and these varieties were of very different genetic backgrounds. The QPM variety was clearly more appreciated than the conventional one, but other varietal differences could have 
played a role. In Kenya, four varieties were tested, of which two were QPM. One QPM variety was well evaluated, but not the other. Again, the varieties were from different backgrounds, so the effect of the QPM trait and that of other varietal characteristics were hard to distinguish. In Ethiopia, similarly, two conventional and two QPM varieties were tested. While QPM varieties were, on average, more appreciated, there was a substantial difference between the conventional as well as between the QPM varieties, with the better conventional variety appreciated similarly to the lesser QPM variety. While the findings were generally consistent across countries and demographic groups, none of the tests strictly isolated the QPM trait and therefore the greater acceptance of QPM varieties may still be due to other varietal differences. To isolate the QPM trait, pairs of near-isogenic varieties should be tested. This should be possible given the common practice of converting existing varieties into QPM by backcrossing ${ }^{16}$.

Further, in Ethiopia, injera from pure teff was much more appreciated than injera from maize of any variety. However, injera with QPM in a 50/50 mixture with teff was generally more appreciated than injera with conventional maize in the same ratio. Therefore, for the same level of acceptance, more QPM can be added, reducing the need for the more expensive teff and thereby reducing the overall cost of injera. In mixtures of $80 \%$ maize, however, the advantage of QPM disappears, indicating the need for further research to evaluate injera with lower levels of maize in the mixture. A study of current practices in mixing injera flour with different cereals in different areas of Ethiopia could provide guidelines for such studies.

Methodologically, this study shows that affective tests are easy and inexpensive to conduct in central locations with African consumers. However, one of the study's limitations is that it selected volunteers rather than individuals randomly drawn from the target population. Rather, these studies were the start of a wider range of studies to develop and test methods for consumer acceptance with the ultimate target audience, rural consumers. The experience with these studies indicates that this method, initially started with urban consumers and later expanded an However, one of the study's limitations is that it selected volunteers rather than individuals randomly drawn from the target population. Rather, these studies were the start of a wider range of studies to develop and test methods for consumer acceptance with the ultimate target audience, rural consumers. The experience with these studies indicates that this method, initially started with urban consumers and later expanded and adapted to rural consumers, is convenient and effective for both groups, and for educated 
as well as illiterate consumers. This was confirmed subsequently by a larger study with rural consumers in Tanzania (which will be reported elsewhere), and based on this experience, the method is currently being applied with rural consumers in Ethiopia.

While we do not claim the participants in this study were representative in a statistical sense, we do not think their opinion differs much from rural consumers, although this needs to be documented. $\mathrm{d}$ adapted to rural consumers, is convenient and effective for both groups, and for educated as well as illiterate consumers. This was confirmed subsequently by a larger study with rural consumers in Tanzania (which will be reported elsewhere), and based on this experience, the method is currently being applied with rural consumers in Ethiopia.

While we do not claim the participants in this study were representative in a statistical sense, we do not think their opinion differs much from rural consumers, although this needs to be documented. While staff at the agricultural research center in Tanzania were likely aware of QPM, very few participants in Kenya and Ethiopia would have been aware. In any case, stringent measures for double blind testing were applied, so this should not influence the test results.

While our study shows how affective tests can be used with African consumers, they should use the proper methodology, in particular double-blinding, which is generally incompatible with promotional demonstrations and should, therefore, be organized separately. Further, the experience of this study indicates that the 9-point scale is convenient with urban, educated consumers, although they almost uniquely used the top five categories only. While the 9-point scale provides a finer resolution than the 5-point scale, the sample size $(n=30)$ was likely too small to distinguish small differences in this evaluation. The 5point scale was convenient for rural and less educated consumers, as it can easily be used on any criterion in any language. As this scale has lower resolution, it needs a larger sample size than a 9-point scale. In this study, however, the responses were well distributed over the scale, and the sample sizes (131 and 120) were large enough to find significant differences for almost all criteria. This scale should be analyzed with ordinal regression, which is relatively straightforward with modern statistical software. However, consumer evaluations typically involve comparisons of several products by the same person, and those are likely to be correlated. Therefore, the analytical model should account for within-person correlation, for example, through the inclusion of a random subject effect. As more biofortified crops and other agricultural technologies and food products are developed to improve the nutrition and 
health of vulnerable populations, methodological development and practice for sensory evaluation and affective tests will be increasingly important.

In this study, we used the terms "good" and "bad" as convenient indicators of quality 30 . The terms "like" and "dislike" are, however, more commonly used in consumer acceptance studies and affective tests ${ }^{22}$. These terms fully embrace the subjective nature of the evaluation in affective tests, as compared with the attempt at objective quality evaluation in sensory evaluation, and should therefore be considered in this type of studies.

In the future, the method tested here needs to be further applied in rural areas. Subsequent studies have already been conducted with rural consumers in Tanzania and are planned with mothers and children in rural Ethiopia. Also, it would be interesting to include an assessment of consumers' willingness to pay for the new products, in particular QPM flour or grain.

While this study shows that consumers can distinguish QPM from conventional maize in a range of criteria, it is not clear what chemical or mechanical properties cause that distinction. More laboratory research is, therefore, indicated to establish these relationships, for example, on the relationship between taste and texture on the one hand, and protein or starch composition and mechanical cohesion on the other hand. Once these relationships are established using near-isogenic QPM-CM pairs, laboratory tests of new varieties can reduce the more costly field and consumer research. Because African consumers, as do their counterparts in many developing countries, typically eat with their hands, the criterion of texture in the hand should be paid special attention.

This study was limited to urban consumers in Tanzania and Ethiopia, and we did not find a difference between urban and rural consumers' preferences in Kenya. In Tanzania, a follow-up study has now been conducted with rural consumers (the results of which will be presented elsewhere), which indicated no difference in acceptance with the urban population. In Ethiopia, acceptance studies with rural consumers, including children, are currently taking place. While the consumers in our study showed a good acceptance of QPM, this does not necessarily translate into willingness to pay a premium. In the Tanzania follow-up study, therefore, consumers' willingness to pay (WTP) was also estimated using an economic experiment. Preliminary results indicate WTP for QPM was positive, and the premium was positively correlated to their consumer acceptance score. Similar results were found in Ghana in a study on consumer acceptance of orange maize, biofortified with provitamin A 
carotenoids ${ }^{43}$. Generally, while consumers seek convenient and healthy products, taste is consistently rated as the most important factor that drives consumption and repeat purchase

of consumers ${ }^{44,45}$. These results lead us to believe there is a market for quality protein maize grain in East Africa. Finally, the current study was done with adults only, while the major target audience are children. Therefore, the study should be repeated with infants and children, as is already planned in Ethiopia.

We conclude that common African maize food products made from QPM can often be distinguished from those made from CM, and are appreciated by African consumers. Moreover, in Ethiopia, use of QPM allows for a higher rate of substitution for the more expensive teff, reducing the cost of injera, the major food preparation. These positive factors can and should be exploited in the promotion of QPM, along with messages on its nutritional benefits.

\section{Acknowledgements}

The authors would like to thank the Canadian International Development Agency (CIDA) for funding this research through the Quality Protein Maize Development (QPMD) Project, the project leader, Dennis Friesen, for his support and encouragement, Simon Kimenju for his help with the Tanzania study, and Kathy Sinclair for editing the manuscript. We further thank CIDA for ongoing support for this research through the Nutritious Maize for Ethiopia (NuME) Project. We appreciate the collaboration with the staff and the enumerators of EHNRI, SARI and KARI and thank the participants in this study for their time and effort. We would like to dedicate this manuscript to our late colleagues and friends, Dr. Wayne L. Haag and Dr. Strafford Twumasi-Afriyie.

\section{References}

1. FAO, IFAD and WFP, The State of Food Insecurity in the World 2013. The multiple dimensions of food security, Ed. FAO, Rome (2013).

2. de Onis M, Blossner M, Borghi E, Frongillo EA and Morris R, Estimates of global prevalence of childhood underweight in 1990 and 2015. Journal of the American Medical Association 291:26002606 (2004).

3. FAO, FAO Statistical Databases (FAOSTAT) [March 11, 2013 2013].

4. HarvestPlus, HarvestPlus Statement on the Potential Benefits of Biofortification on the Nutritional Status of Populations DOI: 
http://www.harvestplus.org/sites/default/files/HarvestPlus_statement_benefits_of_biofortification _8-17-10.pdf (2010).

5. Bouis HE, Economics of enhanced micronutrient density in food staples. Field Crops Research 60:165-173 (1999).

6. Meenakshi JV, Banerji A, Manyong V, Tomlins K, Hamukwala P, Zulu R and Mungoma C, Consumer Acceptance of Provitamin A Orange Maize in Rural Zambia. HarvestPlus Working Paper No.4, Ed. IFPRI, Washington, D. C. (2010).

7. Lauderdale J, Issues Regarding Targeting and Adoption of Quality Protein Maize (QPM). CIMMYT (International Maize and Wheat Improvement Center), Mexico D.F. (2000).

8. Pellett PL, World Essential Amino Acid Supply with Special Attention to South-East Asia. Food and Nutrition Bulletin 17:204-234 (1996).

9. Vasal SK, The quality protein maize story. Food and Nutrition Bulletin 21:445-450 (2000).

10. Mertz ET, Bates LS and Nelson OE, Mutant gene that changes protein composition and increases lysine content of maize endosperm. Science 145:279-280 (1964).

11. Prasanna BM, Vasal SK, Kassahun B and Singh NN, Quality protein maize. Current Science 81:1308-1319 (2001).

12. Akalu G, Taffesse $S$, Gunaratna NS and De Groote $H$, The effectiveness of quality protein maize in improving the nutritional status of young children in the Ethiopian highlands. Food and Nutrition Bulletin 31:418-430 (2010).

13. Singh J, Koshy S, Agrawal KN, Lodha ML, Singh NN and Sethi AS, Relative efficacy of opaque-2 maize in the growth of preschool children. Indian Journal of Nutrition and Dietetics 17:326-334 (1980).

14. Ortega Alemán EC, Romero AJC, Argueta LIO and Pachón H, Efectos de la ingesta de maíz de alta calidad de proteína (QPM) versus maíz convencional en el crecimiento y la morbilidad de niños nicaragüenses desnutridos de 1 a 5 años de edad. Archivos Latinamericanos de Nutricion 58:377-385 (2008).

15. Gunaratna NS, De Groote H, Nestel P, Pixley KV and McCabe GP, A Meta-analysis of Community-level Studies on Quality Protein Maize. Food Policy 35:202-210 (2010).

16. Atlin GN, Palacios N, Babu R, Twumasi-Afriye S, De Groote H, Vivek B, Friesen D and Pixley KV, Quality Protein Maize: progress, impact, and prospects. Plant Breeding Reviews 34:83-130 (2010).

17. Pardo FT, Mora JO, Paez JF, De Onshuss Y and De La Cruz de Villota M, Aceptabilidad del Maize Opaco-2 en Colombia. Archivos Latinamericanos de Nutricion 22:561-575 (1972).

18. Ahenkora K, Twumasi-Afriyie S, K. SPY and Obeng-Antwi K, Protein nutritional quality and consumer acceptability of tropical Ghanaian quality protein maize. Food and Nutrition Bulletin 20:354-360 (1999).

19. Martins JL, Jideani IA, Yusuf IZ and Tahir F, Comparative consumer acceptability and food utilization analysis of three maize varieties. Nutrition \& Food Sciences 40:323-329 (2010).

20. Krivanek AF, De Groote H, Gunaratna NS, Diallo AO and Friesen D, Breeding and Disseminating Quality Protein Maize (QPM) for Africa. African Journal of Biotechnology 6:312-324 (2007).

21. Lancaster KJ, A New Approach to Consumer Theory. Journal of Political Economy 74:132-157 (1966).

22. Meilgaard M, Civile GV and Carr BT, Sensory Evaluation Techniques 4th Edition. CRC Press, Florida, USA (2007).

23. Likert R, A technique for the measurement of attitudes. Archives of Psychology 22:1-55 (1932).

24. Mazengo MC, Simell O, Lukmanji Z, Shirima R and Karvetti RL, Food consumption in rural and urban Tanzania. Acta Tropica 68:313-326 (1997).

25. De Groote $\mathrm{H}$ and Kimenju SC, Consumer preferences for maize products in urban Kenya. Food \& Nutrition Nutrition Bulletin 33:99-110 (2012). 
26. Ouma JO, De Groote H and C.J.Mutinda, Assessing Field and Sensory attributes of QPM for acceptability, 11th KARI biennial scientific conference, 10th -14th November, 2008, Nairobi, kenya. (2008).

27. Stewart RB and Getachew A, Investigations of the Nature of Injera. Economic Botany 16:127130 (1962).

28. Cherinet $\mathrm{H}$, Development of flours using traditional food crops for making injera. Terminal report. FAO, Addis Ababa (1988).

29. Stevens SS, On the Theory of Scales of Measurement. Science 103:677-680 (1946).

30. Rohrmann B, Verbal qualifiers for rating scales: Sociolinguistic considerations and psychometric data. Project Report. (2007).

31. Connett JE, Smith JA and McHugh RB, Sample size and power for pair-matched case-control studies. Statistics in medicine 6:53-59 (1987).

32. Julious SA and Campbell MJ, Sample size calculations for paired or matched ordinal data. Statistics in medicine 17:1635-1642 (1998).

33. Julious SA, Campbell MJ and Altman DG, Estimating sample sizes for continuous, binary, and ordinal outcomes in paired comparisons: practical hints. Journal of Biopharmaceutical Statistics 9:241-251 (1999).

34. McCullagh P, Regression Models for Ordinal Data. Journal of the Royal Statistical Society Series B (Methodological) 42:109-142 (1980).

35. Coe R, Analyzing ranking and rating data from participatory on-farm trials, in Quantitative analysis of data from participatory methods in plant breeding, ed. by Bellon MR and Reeves J. CIMMYT, Mexico, DF, pp 46-65 (2002).

36. De Groote H, Rutto E, Odhiambo G, Kanampiu F, Khan Z, Coe R and Vanlauwe B, Participatory evaluation of integrated pest and soil fertility management options using ordered categorical data analysis. Agricultural Systems 103:233-244 (2010).

37. Maddala GS, Limited-dependent and qualitative variables in econometrics. Cambridge University Press, New York (1983).

38. Greene WH, Econometric Analysis. Mcmillan Publishing Company, New York (1991).

39. Train KE, Discrete Choice Methods with Simulation. Cambridge University Press (2003).

40. Bellon MR, Adato M, Becerril J and Mindek D, Poor farmers' perceived benefits from different types of maize germplasm: The case of creolization in lowland tropical Mexico. World Development 34:113-129 (2006).

41. De Groote H, Kimenju SC and Morawetz UB, Estimating consumer willingness to pay for food quality with experimental auctions: the case of yellow versus fortified maize meal in Kenya.

Agricultural Economics 42:1-16 (2011).

42. Pellett PL and Ghosh S, Lysine Fortification: Past, Present, and Future. Food and Nutrition Bulletin 25:107-113 (2004).

43. Banerji A, Chowdhury S, De Groote H, Meenakshi JV, Haleegoah J and Ewool M, Using Elicitation Mechanisms to Estimate the Demand for Nutritious Maize: Evidence from Experiments in Rural Ghana. HarvestPlus Working Paper No. 10, Ed (2013).

44. Cardello AV, Schutz HG and Lesher LL, Consumer perceptions of foods processed by innovative and emerging technologies: A conjoint analytic study. Innovative Food Science \& Emerging Technologies 8:73-83 (2007).

45. Grunert KG, Bech-Larsen T and Bredahl L, Three issues in consumer quality perception and acceptance of dairy products. International Dairy Journal 10:575-584 (2000). 


\section{Appendix. Translation of terms used for scores and criteria during affective tests}

\begin{tabular}{|c|c|c|c|}
\hline English & $\begin{array}{l}\text { Kiswahili } \\
\text { (Tanzania) }\end{array}$ & Kiembu (Kenya) & $\begin{array}{l}\text { Amharic } \\
\text { (Ethiopia) }\end{array}$ \\
\hline \multicolumn{4}{|l|}{ Scores } \\
\hline Extremely bad & Mbaya kabisa & & \\
\hline Very bad & Mbaya sana & Mbega Muno & Betam Metfo \\
\hline Bad & Mbaya & Mbega & Metfo \\
\hline Moderately bad & Mbaya kidogo & & \\
\hline Fair & Wastani & Ciiganene & Beki \\
\hline Moderately good & Nzuri kidogo & & \\
\hline Good & Nzuri & Njuku & Tiru \\
\hline Very good & Nzuri sana & Njuku Muno & Betam Tiru \\
\hline Excellent/extremely & Nzuri kabisa & & \\
\hline \multicolumn{4}{|l|}{ Criteria } \\
\hline Aroma & Harufu & & Ye injeraw Meaza \\
\hline Appearance & Muonekano & Mwigana wa & Ye injeraw ayn huneta ena \\
\hline Texture & Chembechembe & & \\
\hline Texture in the hand & Chembechembe mkononi & Utotu wa mbembe & Ye injeraw lisilassie \\
\hline $\begin{array}{l}\text { Texture in the mouth } \\
\text { Pliability }\end{array}$ & Chembechembe mdomoni & & $\begin{array}{l}\text { Ye injeraw aff wist lisilassie } \\
\text { Ye injeraw dirket }\end{array}$ \\
\hline Taste & Ladha & Musamo & Ye injeraw Ta'em \\
\hline Overall & Kwa ujumla & & Ateqalay teqebayinet \\
\hline
\end{tabular}




\section{Supplementary material to the paper}

Consumer Acceptance of Quality Protein Maize (QPM) in East Africa

Reference: JSFA-13-2357
1. Kenya
2. Ethiopia
3. Tanzania 


\section{Questionnaire for consumer acceptance - Kenya}

\section{A. Urban consumers}

\section{General information}

1. Participant name: First:

Last:

Participant number:

2. Sex of participant: $M / F$

3. Age $<20,20-30,31-40,41-50,>50$ (tick)

4. Formal education? (Years of school completed)

Score the samples provided against the attributes by ticking the appropriate cell

\begin{tabular}{|l|l|l|l|l|l|l|}
\hline Sample & Attribute & Very Poor & Poor & Average & Good & Very Good \\
\hline First & Taste & & & & & \\
\hline & Appearance & & & & & \\
\hline & Texture & & & & & \\
\hline & Overall & & & & & \\
\hline Second & Taste & & & & & \\
\hline & Appearance & & & & & \\
\hline & Texture & & & & & \\
\hline & Overall & & & & & \\
\hline Third & Taste & & & & & \\
\hline & Appearance & & & & & \\
\hline & Texture & & & & & \\
\hline & Overall & & & & & \\
\hline Fourth & Taste & & & & & \\
\hline & Appearance & & & & & \\
\hline & Texture & & & & & \\
\hline
\end{tabular}




\begin{tabular}{|l|l|l|l|l|l|l|}
\hline & Overall & & & & & \\
\hline
\end{tabular}




\section{B. Rural consumers}

Location

District

Division
,Farmer identification number Location
Sublocation/Village:

\section{General information}

1. Farmers name: First: Last:

2. Sex of the farmer:

5. Formal education? Years of school completed)

6. What is the size of your farm? acres,

7. Area under maize: acres

Livestock ownership (number of animals owned, by species):

Dairy cows:

Goats

Poultry

Sheep

Self-sufficiency in maize (Y/N)

What $\%$ of maize is sold:

If no, number of months $\%$

Score the samples provided against the attributes by TICKING the appropriate cell

\begin{tabular}{|c|c|c|c|c|c|c|}
\hline Sample & Attribute & $\begin{array}{l}\text { Njuku } \\
\text { muno } \\
\text { (very } \\
\text { poor) }\end{array}$ & $\begin{array}{l}\text { Njuku } \\
\text { (poor) }\end{array}$ & $\begin{array}{l}\text { Ciiganene } \\
\text { (average) }\end{array}$ & $\begin{array}{l}\text { Mbega } \\
\text { (good) }\end{array}$ & $\begin{array}{l}\text { Mbega } \\
\text { muno (very } \\
\text { good) }\end{array}$ \\
\hline \multirow[t]{4}{*}{ First } & Musamo (taste) & & & & & \\
\hline & $\begin{array}{l}\text { Mwigana wa mbembe } \\
\text { (appearance) }\end{array}$ & & & & & \\
\hline & $\begin{array}{l}\text { Utotu wa mbembe } \\
\text { (Texture) }\end{array}$ & & & & & \\
\hline & Jumla (overall) & & & & & \\
\hline \multirow[t]{4}{*}{ Second } & Musamo & & & & & \\
\hline & Mwigana wa mbembe & & & & & \\
\hline & Utotu wa mbembe & & & & & \\
\hline & Jumla & & & & & \\
\hline \multirow[t]{4}{*}{ Third } & Musamo & & & & & \\
\hline & Mwigana wa mbembe & & & & & \\
\hline & Utotu wa mbembe & & & & & \\
\hline & Jumla & & & & & \\
\hline \multirow[t]{2}{*}{ Fourth } & Musamo & & & & & \\
\hline & Mwigana wa mbembe & & & & & \\
\hline
\end{tabular}




\begin{tabular}{|l|l|l|l|l|l|l|}
\hline & Utotu wa mbembe & & & & & \\
\hline & Jumla & & & & & \\
\hline
\end{tabular}

\section{Questionnaire for ugali CLT in Tanzania}

\section{Introduction}

Dear Sir/Madam, we are researchers in agriculture and we would like to lead you as we undertake some few experiments on stiff porridge.

Identification (Enumerators to fill in the names, supervisors to provide the codes)

Date of experiment: (dd/mm/year)

Starting time (hourrs and minutes in 24 hourr clock)

Respondent first name: Last name

Respondent's number

Identifying Variables:

Country:

Admin 1 (District):

Admin 2 (Division/County/PA):

Admin 3 (Ward/Sub-County):

Admin 5 (Village/Local Council 1):

Supervisor first name:

Date checked: (Dd/Mm/Year) CHDATE

Date entered: (Dd/Mm/Yr) ENTDATE

Entered by: First name:
COCODE:

ADMIN1: ADMIN2: ADMIN3:

ADMIN5: Last name SUPCODE

DECODE

2. Sex of the respondent ( $1=$ Female, $2=$ Male $)$ REGEND_

3. Marital status of the respondent? MSATRES

(1=married; $2=$ single; $3=$ windowed; $4=$ divorced; $5=$ separated; $6=$ other (specify)

4. Age of the respondent (in years)? AGERES

5. Education (number of years in formal education); EDUCRES

6. What is your employment status? OCCUP ( $1=$ work on family farm; $2=$ salaried employment in private sector, govt, NGO; $3=$ casual laborer; $4=$ self-employed business, not farm; $5=$ Not employed; $6=$ Other specify 
Part A: Sensory Testing

Instructions: In front of you, you will find two plates of stiff porridge and a bottle of water. You will be required to do the sensory evaluation of the two stiff porridge according to the order given to you ( $50 \%$ will be required to start with stiff porridge ...... and $50 \%$ will be required to start with stiff porridge ...... ).

Please evaluate the stiff porridge in terms of:

1. Appearance

2. Texture in the hand (Hand-feel)

3. Aroma (smell)

4. Texture in the mouth (Mouth-feel) and

5. Taste.

6. Overall evaluation

You are required to evaluate the stiff porridge in terms of how good each is, and use a rating of 1 to 9 for each evaluation to mean:

$1=$ extremely bad

$2=$ very bad

$3=\mathrm{bad}$

$4=$ moderately bad

$5=$ fair

$6=$ moderately good

$7=$ good

$8=$ very good

$9=$ excellent/extremely good

Give a genuine opinion about your sensory evaluation of the stiff porridge. Before you start the tasting, rinse your mouth using the water provided, and also drink some water to clean your palate. After you finish evaluating the first stiff porridge, and before you start evaluating the second stiff porridge, rinse your mouth and drink some water. Follow these guidelines:

- Aroma (smell): take short sniffs of the stiff porridge as soon as you uncover the porridge,

- Appearance (impression of the colour),

- Texture in the hand (hand-feel): break a piece of the cooked stiff porridge and rub it gently between the middle fingers and the thumb to feel the texture/touch,

- Texture in the mouth (mouth-feel): put a piece of cooked stiff porridge in your mouth and feel the grittiness when chewed and swallowed.

- Taste/flavor: Swallow the chewed stiff porridge and evaluate its overall taste/flavour when swallowing.

- Overall evaluation: Evaluate the overall stiff porridge 


\section{Consumer acceptance tests for different maize varieties Ethiopia - Data collection sheet}

A. Panelist records (information of all panellists recorded on one sheet):

Date:

\begin{tabular}{|l|l|l|l|l|l|}
\hline $\begin{array}{l}\text { Code } \\
\text { (number) }\end{array}$ & Name & Sex & Age & $\begin{array}{l}\text { Educational } \\
\text { level } \\
\text { (finished) }\end{array}$ & $\begin{array}{l}\text { Number of years in } \\
\text { formal schooling }\end{array}$ \\
\hline & & & & & \\
\hline & & & & & \\
\hline & & & & & \\
\hline & & & & & \\
\hline & & & & & \\
\hline & & & & & \\
\hline & & & & & \\
\hline & & & & & \\
\hline & & & & & \\
\hline & & & & & \\
\hline
\end{tabular}

Educational level: 1=No formal education, 2=Primary school, 3=Secondary education, 4=Higher education 
B. Score sheet for sensory evaluation of prepared food products (one sheet per product)

Panelist code:

Date:

Product code:

Product order :

\begin{tabular}{|l|l|l|l|l|l|}
\hline & \multicolumn{2}{|l|}{ Score } & \multicolumn{3}{|l|}{} \\
\hline QUALITY ATTRIBUTES & 1 & 2 & 3 \\
(very poor) & (poor) & (fair) & $\begin{array}{l}\text { (good) } \\
\text { (very } \\
\text { good) }\end{array}$ \\
\hline Appearance (eye distribution \& underside) & & & & & \\
\hline Texture in the hand & & & & & \\
\hline Pliability (Elasticity) & & & & & \\
\hline Aroma & & & & & \\
\hline Texture in the mouth & & & & & \\
\hline Taste & & & & & \\
\hline Overall acceptance & & & & & \\
\hline
\end{tabular}

Comment if any: 